\title{
AN ANALYSIS OF TEACHER QUESTIONING IN THE CLASSROOM INTERACTION
}

\author{
Reni Apriani' ${ }^{1}$, Diana Marchelina ${ }^{2}$ \\ ${ }^{1}$ IKIP Siliwangi \\ ${ }^{2}$ IKIP Siliwangi \\ ${ }^{1}$ Apriligory666@gmail,com ,2 Dianamarchelina.13031501@gmail.com
}

\begin{abstract}
Teaching learning process will be effective when there are interactions between the teacher and students. Classroom interaction is one of the crucial factors in the teaching-learning process. Questioning has been recognized as the equipment of classroom teachers and profound to prominent teaching. The objective of this research is to identify the types of basic questions the teacher asks. The research method used descriptive qualitative design. The data were obtained by doing observation and interview with the educator and students as respondent. The population of this research was teacher and students of the second-grade students of SMK TI Garuda Nusantara Cimahi. The data were investigated by applying questioning strategies focused on the variety of teacher questioning. The result showed that entire teacher questioning that found the most frequently used. Based on the result, it can be concluded that the questioning from the teacher was more dominant than student questions.
\end{abstract}

Keywords: Teacher questioning, Classroom interaction, Questioning strategies, Type of questions.

\section{INTRODUCTION}

Teaching English has formulated impressively in recent years because of the globalization impact. In this global era, people need to share their ideas and interact with the other people in English. According to Pianta (2016), interactions between the educator with the educatee is a primary key to improve student learning and development. Classroom interaction is one of the important factors in the teaching-learning process. According to Brown (2000), interaction is the interactive climate to create the teacher questioning is need the collaborative exchange of thought, sensitivity, or thought between a teacher and learners and other learners resulting in the reciprocal effect of each other. Interaction in the linguistic communication class is different from other interaction; in language classroom interaction is a activity of the learning process of studying the language.

The fundamental outstanding of teaching Questioning has always been acknowledged as the stock-in-trade of classroom teachers (Frazee \& Rudnitski, 1995; Nunan \& Lamb, 1996). The teacher focus students' attention to arouse their curiosity, understand lesson content, excite their imagination, and motivate them to find out new knowledge, that is believed in effective questioning. Teacher's question could be act as a trigger for students to engage students minds more actively (Chin \& Osborne, 2008). The problem which is going to be mainly investigated here is types of 'teachers' questions in the reality, effective questioning does not always happen, even among teachers with considerable experience in teaching.

\section{Teacher Questioning}

Questioning holds a critical duty in teaching. Students are the center of learning, students gain a knowledge through questioning process. However, students need guidance to obtain their 
goals. Teachers as a learning facilitator must be competent to give their guidance. In other words, the teacher must help the students with their questioning ability.

Questions must be specifically designed for various students ability. Questioning techniques that should be used are the techniques that will stimulate widest students' attendance. Not only questions, statements should also encourage students. One questioning strategy may only apply to only one teaching condition. The question describes as an interrogative expression command or used to gain information or a response, it is generally used to test a knowledge. Lynch (1991), however, criticizes that question are not always related with measuring knowldege.

\section{The importance of Questioning}

The critical part of teaching is questioning. Teachers must have the skill and manner and have full of knowledge in constructing questions. Thus, teachers can assist the student through the questioning process. Questions can be the important aspect for teachers to use to encourage student thinking (Harvey \& Goudvis, 2007; Marzano, 2007).

a. Research on Questioning

I provide empirically tested and validated techniques are easy to use and more important, that invigorate classroom recitation. Recitation is a learning technique in which the teacher calls on different students to answer factual or knowledge-based questions that limit students to one "correct" response.

b. Using Students' Questioning Summarizations

Teachers need to try hard not to determinate classroom interactions and cause class members to become passive and dependent on the teacher. Student passivity hardly fosters ingenuity, creativity, or critical thinking-traits we all consider describe. Students contribution rose when teacher gave the opportunity to students to follow-up the quesions (Wells \& Arauz, 2006).

\section{Questioning Strategies}

According to Orlich, Harder, Callahan, Trevisan, \& Brown (2012), the four questioning strategies are the divergent, convergent, evaluative and reflective questioning to delegate particular value to the different form of questioning. In the classroom, teachers questioning is a distinguished feature in classroom communication (Chin, 2007) .

\section{Appropriate Questioning Behaviors}

A relevant questioning behavior to improve an acceptable questioning ability is to be apprehensive of extensive kinds of techniques for extracting relevant responses from the student. The questioning competency that applicable to the specific form of problems may grow in class using questioning strategies. The basic rule for asking questions is to proceed in three steps: ask the question, pause, and then call on a student.

\section{Classroom Interaction}

According to Brown (2007), classroom interaction is a collaborative dealings of ideas between two people or more, of thoughts, feelings, for resulting in a reciprocal effect on each other, that is the interaction. The concept of communicative ability accentuate the role of language use in diverse context to negotiate substance in human experience. In other words, to get the idea from someone's mind into others' mind and vice versa.

From the statement above, the investigator wants to share about which type of teacher questions that frequently use in the classroom interaction. So, the researcher will take the title "An Analysis of Teacher Questioning in the classroom interaction". 


\section{METHOD}

As mentioned before that the aim of this study is to investigate what type of teacher questions frequently use. Thus, in order to discover the result, this study contains the description of the steps that have been taken this study. The method of this research is a Qualitative method. In this case to describe, the advantage and disadvantages of teacher questioning in the classroom and to uncovering the type of teacher questioning and learner in the classroom interaction.

\section{RESULTS AND DISCUSSION}

\section{Results}

Researchers conducted a field study to find information and data that has been prepared in advance. In obtaining the information, the researchers ask questions through observation and by interviewing the teacher and class participant. Here is a description of the observation and interviews with the teacher:

Interviewer: Writer

Respondent: Teacher

a. W: Do you usually ask a question to students by their knowledge of the fact that is specific?

T: Yes, because to make them know about English such as "how are you?", "what are you doing?"

b. W: How do you respond when the answer different from the students or make them difficult to answer?

T: I just give smile first, then I repeat the question. But if they still can't understand I usually translate to Bahasa.

c. W: What does the teacher provide an evaluating of the answers to each student?

$\mathrm{T}$ : With give a praise although their answer is not appropriate for my question. But I always give evaluation with telling the right answer to the student.

d. W: What do you do to make students more confident in answering questions critically and analytically?

T: Let them free to ask to share their expression so that they are not afraid to ask a question

e. W: When you want to give it the more difficult question or questions that more increased than before, what do you prepare?

f. W: How student responses when given the difficult questions that require them to give a statement, conclusion individually?

T: They are very enthusiasm although their answer is not always right. But in the end, I always give them the evaluation of their answer.

g. W: What does the teacher do to handle the students who cannot answer the questions or give the wrong answer?

T: I usually tell the right answer

h. W: Do you usually like give rewards to students who successfully answered the question?

T: I usually read the other resource such as browsing the internet, then I prepare a question for the student.

T: Yes, of course. Because this is the easier manner to make them more motivated and active in the classroom. And I think this is very important to do by the teacher. 
The components of writing skill, the score, and the Description

\section{1) Student 1}

a. W: What kind of questions that are frequently asked by your teacher, difficult or easy questions?

ST: Easy, because it is easy to understand

b. W: What does the teacher respond when your answer is different?

ST: My teacher does not feel angry because if the student is giving a different answer it means that we think my own self.

c. W: What does the teacher give an evaluation from answer different on you?

ST: give explanation again so that we can understand

d. W: When your teacher asked a question the reasons and consequences, how do you handle it?

ST: Think so hard so that the answer can be logical

e. W: What does the teacher respond when your answer is wrong? How to provide direction, encouragement, and evaluation?

ST: Just explain again our mistake and give the right answer.

f. W: Does your teacher often provide questions that require you to answer in detail to provide a statement widely?

ST: Yes, so that we get more knowledge.

g. W: Does the teacher usually give the opportunity for students to ask the question or give the opinion?

Here is a description of the results of interviews with three students who can be described as follows:

ST: Yes, because my teacher always gives the explanation of what we don't understand.

h. W: What are the teacher responses to you when you successfully answer the questions?

ST: My teacher feels happy and gives congratulation to us because we can understand the material.

2) Student 2

a. W: What kind of questions that are frequently asked by your teacher, difficult or easy questions?

ST: Easy. Because easy to understand.

b. W: What does the teacher respond when your answer is different?

ST: Happy, because if the student has a different opinion it means that we are thinking my own self and not cheating.

c. W: What does the teacher give an evaluation from answer different on you?

ST: Explain again if we are not understanding.

d. W: When your teacher asked a question the reasons and consequences, how do you handle it?

ST: We always ask again if we are not understanding.

e. W: What does the teacher respond when your answer wrong? How to provide direction, encouragement, and evaluation?

ST: Explain and tell our mistake then give the right answer.

f. W: Does your teacher often provide questions that require you to answer in detail to provide a statement widely?

ST: Yes, so that our knowledge is increasing.

g. W: Does the teacher usually give the opportunity for students to ask the question or give the opinion?

ST: Yes, after the teacher gives the explanation about the material.

h. W: What are the teacher responses to you when you successfully answer the questions? 
ST: Happy, it means my teacher has succeeded in teaching the student, so that

3) Student 3

a. W: What kind of questions that are frequently asked by your teacher, difficult or easy questions?

ST: Sometimes easy but sometimes also difficult, so that we can think so hard to answer.

b. W: What does the teacher respond when your answer is different?

ST: My teacher always patient and repeat again about the right answer so we can understand.

c. W: What does the teacher give an evaluation from answer different on you?

ST: Give the explanation for the right answer.

d. W: When your teacher asked a question the reasons and consequences, how do you handle it? We usually ask again if we are not understanding.

ST: Explain and tell our mistake, then give the right answer.

e. W: What does the teacher respond when your answer wrong? How to provide direction, encouragement, and evaluation?

ST: Giving explanation and tell our mistake.

f. W: Does your teacher often provide questions that require you to answer in detail to provide a statement widely?

ST: Yes, after giving the explanation about the material.

g. W: Does the teacher usually give the opportunity for students to ask the question or give the opinion?

ST: Yes, my teacher always asks about the material to make sure that we have understood.

h. W: What are the teacher responses to you when you successfully answer the questions? ST: My teacher always gives a praise by adding the score for us.

According to the dialogue above, it can be described that the teacher always gives the easiest questions as called basic question, such as "how are you?" "Is there any questions?", "what do you think about?" etc. The questions that always asked by the teacher is based on their knowledge. Most of the students can answer teacher's questions because the teacher always give repetition for each question to make sure that students can understand what the teacher's mean.

\section{Discussion}

From every interaction conducted in the classroom, the researchers found that in the type of teacher questioning, asking question and lecturing are most commonly existing in the classroom interaction.

\section{CONCLUSION}

The finding of this research on teacher questioning can be summed up "which type of basic questions are most frequently asked by the teacher?". The type of basic questions teachers ask can make a significant difference in student achievement. A review of research on teacher questioning indicates that the teacher always gives the easy question and always ask about students' conditions and also always ask does the student ready to study before start teachinglearning process. 


\section{ACKNOWLEDGMENTS}

Praise God Almighty, for the presence of plenty of mercy and his grace. So that the writers can complete the thesis with the title: An Analysis of Teacher Questioning in the Classroom interaction. Appreciation and thanks the author gave to Ratih Inayah, S.Pd.,M.Pd as a Supervisor, IKIP Siliwangi Bandung for comments that greatly improved the manuscript.

\section{REFERENCES}

Brown, H. D. (2000). Teaching By Principle: An Interactive Approach In Language Pedagogy (2nd Ed.). San Francisco: Longman.

Brown, H. D. (2007). Principle Of Language Learning And Teaching (5th Ed.). San Francisco: Longman.

Chin, C. (2007). Teacher Questioning In Science Classrooms: Approaches That Stimulate Productive Thinking. Journal Of Research In Science Teaching, 44(6), 815-843. Https://Doi.Org/10.1002/Tea

Chin, C., \& Osborne, J. (2008). Students' Questions: A Potential Resource For Teaching And Learning Science. Studies In Science Education, 44(1), 1-39. Https://Doi.Org/10.1080/03057260701828101

Frazee, B., \& Rudnitski, R. A. (1995). Integrated Teaching Methods: Theory, Classroom Applications, And Field-Based Connections. Delmar Pub.

Harvey, S., \& Goudvis, A. (2007). Strategies That Work: Teaching Comprehension For Understanding And Engagement (2nd Ed.). Stenhouse Publishers.

Lynch, T. (1991). Questioning Roles In The Classroom. ELT Journal, 45(3), 201-210. Https://Doi.Org/10.1093/Elt/45.3.201

Marzano, R. J. (2007). The Art And Science Of Teaching: A Comprehensive Framework For Effective Instruction. Ascd.

Nunan, D., \& Lamb, C. (1996). The Self-Directed Teacher: Managing The Learning Process. Cambridge University Press.

Orlich, D. C., Harder, R. J., Callahan, R. C., Trevisan, M. S., \& Brown, A. H. (2012). Teaching Strategies: A Guide To Effective Instruction. Cengage Learning.

Pianta, R. C. (2016). Teacher-Student Interactions. Policy Insights From The Behavioral And Brain Sciences, 3(1), 98-105. Https://Doi.Org/10.1177/2372732215622457

Wells, G., \& Arauz, R. M. (2006). Dialogue In The Classroom. Journal Of The Learning Sciences, 15(3), 379-428. Https://Doi.Org/10.1207/S15327809j1s1503_3 